\title{
A note on the chemical composition of the cotyledons and seed coat of three species of sweet lupin
}

\section{Stefania Smulikowska, Justyna Wasilewko and Anna Mieczkowska}

\author{
The Kiclanowski Institute of Animal Physiology and Nutrition, \\ Polish Academy of Sciences \\ 05-110 Jahlonna near Warsaw, Poland
}

(Received 14 February 1995; accepted 8 March 1995)

\begin{abstract}
Nine varieties of sweet lupins, harvested in Poland during 1993 (yellow: Juno, Popiel and Amulet; white: Wat, Bardo and Iletman; narrow-leaved: Sur, Emir and Saturn), differing in the size of seeds, were dehulled by hand. The chemical composition of whole seeds, hulls and dehulled secds were determined.

The size of seeds (expressed as the weight of 1000 seeds) of white and narrow-leaved lupins was positively correlated with the cotyledons and protein and fat contents in the seeds. In all varietics about $97 \%$ of total protein and 95 to $98 \%$ of total fat contained in the secds werc found in the colyledons, 74 to $86 \%$ of total crude fibre in the hulls. Dehulling of lupin seeds may increase their metabolizable energy content for poultry by 20 to $35 \%$.
\end{abstract}

KEY WORDS: L. luteus, L. albus, L. angustifolius, hull, cotyledon, chemical composition

\section{INTRODUCTION}

Sweet lupin seeds are a potentially important source of protein for monogastric animals. Their nutritional value also depends on fat content, which is not only a source of energy, but also a rich source of essential unsaturated fatty acids. According to Matyka and Przegalińska (1986) they can constitute up to $56.5 \%$ of total fatty acids in yellow lupins, about $60 \%$ in white and $30-40 \%$ in narrow-leaved lupins. However, the content of dietary fibre is also high in lupin seeds. It is poorly digested in the small intestine of pigs (Gdala et al., 1994) and digested only to a very small extent by chicks (Alloui et al., 1994). 
Most of the dietary fibre is concentrated in hulls which, according to Brillouet and Riochet (1983), make up from 16 to $28 \%$ of the whole seed in different species of lupin. Systematic observations made in our laboratory (Wasilewko, unpublished) indicated that different varieties representing three species of lupin recently cultivated in Poland ( $L$. luteus, $L$. albus and L. angustifolius) may differ greatly in the size of the seeds. However, there is little evidence on the relative proportion of hulls in lupin seeds of different genetic origin.

The aim of the study was to recognize if there is a relationship between the size of the seed, proportion of hulls in it, and partitioning of the main nutrients (protein and fat) and fibre, between the colyledon and hull fractions in seeds of different genetic origin.

\section{MATERIAL AND METHODS}

Nine varieties of sweet lupins representing 3 species harvested in Poland during 1993 and differing in seed size (measured as the weight of 1000 seeds) were investigated. They were: Juno, Popiel and Amulet (L. luteus); Wat, Bardo and Hetman (L.albus) and Sur, Emir and Saturn (L. angustifolius).

One kg samples of seeds were soaked in distilled water at $6^{\circ} \mathrm{C}$ overnight and dehulled by hand. The hulls and cotyledons were collected quantitatively and germs were included with the cotyledons. The hulls and cotyledons were dried in $90^{\circ} \mathrm{C}$, weighed and finely ground on a Cyclotec 1090 Sample Mill (Tecator).

The dry matter (DM) content was determined by oven-drying at $105^{\circ} \mathrm{C}$ and all further analyses were reported on DM basis. Crude protein $(\mathrm{N} \times 6.25)$, ash, fat and fibre content in seeds, hulls and cotyledons were detcrmined according to standard methods (AOAC, 1990) and the nitrogen-free extractives (NFE) content calculated from the difference. Neutral detergent (NDF) and acid detergent (ADF) fibre and acid detergent lignin (ADL) were determined according to Van Soest and Wine (1967) on a Fibertec M (Tecator) apparatus.

\section{RESULTS AND DISCUSSION}

Significant differences in the size of seeds (expressed as the weight of 1000 seeds) were found among the three investigated lupin species (Table 1). The weights of 1000 seeds ranged between 115 and $274 \mathrm{~g}$ in L. luteus, between 274 and $454 \mathrm{~g}$ in L. albus and between 137 and $196 \mathrm{~g}$ in L. angustifolius. In L. luteus no correlation between the size of the seed and the hull content in the seed was found, the average content of the hull was $24.5 \%$. A lower (22.55\%) proportion 
TABLE 1

Size of lupin seeds and proportion of hulls and cotyledons

\begin{tabular}{lcccc}
\hline Lupin & $\begin{array}{c}\text { Weight, } \\
\text { g/1000 secds }\end{array}$ & $\begin{array}{c}\text { Dry matter, } \\
\% \text { of whole secd }\end{array}$ & $\begin{array}{c}\text { Hull, \% of } \\
\text { whole sced DM }\end{array}$ & $\begin{array}{c}\text { Cotyledons, \% of } \\
\text { whole seed DM }\end{array}$ \\
\hline $\begin{array}{l}\text { L. luteus } \\
\text { Juno }\end{array}$ & 132 & 89.22 & 25.42 & 74.58 \\
$\quad$ Popiel & 274 & 88.06 & 24.58 & 75.42 \\
$\quad$ Amulet & 115 & 89.97 & 24.52 & 75.48 \\
L. albus & & & & \\
$\quad$ Wat & 274 & 92.46 & 24.08 & 75.92 \\
$\quad$ Bardo & 326 & 88.16 & 19.60 & 80.40 \\
Hetman & 454 & 92.01 & 17.59 & 82.41 \\
L. angustifolius & & & & \\
$\quad$ Sur & 137 & 90.46 & 24.68 & 75.32 \\
$\quad$ Emir & 196 & 90.58 & 20.02 & 79.98 \\
$\quad$ Saturn & 172 & 90.46 & 23.53 & 76.47 \\
\hline
\end{tabular}

of hulls was reported for the Juno variety by Zdunczyk et al. (1994), but much higher $(27.2 \%)$ by Brillouet and Riochet (1983) for LL29 cv. There was a significant negative correlation between the size of the seed and the hull content in L. albus $(\mathrm{r}=-0.898)$ as well as in L. angustifolius $\mathrm{P}(\mathrm{r}=-0.924)$. Also Brillouet and Riochet (1983) reported that the hull proportion in 5 cultivars of $L$. albus depended on the size of the seed $(r=-0.89)$, but the proportion of hulls in 10 other species of lupin evaluated by them was not correlated with the weight of 1000 seeds.

Whole seeds of $L$. luteus contained on average (DM \%) $42.44 \pm 1.1 ; L$. albus $31.31 \pm 3.5$ and $L$. angustifolius $32.19 \pm 2.78$ of crude protein (Table 2). The protein content was lower than that reported for the same varieties but harvested in 1991 (Alloui et al., 1994), probably due to unfavourable weather conditions during vegetation in 1993. The differences in respective fat contents (Table 2) and that reported by Alloui et al., (1994) were smaller, only $L$. albus contained more fat than reported in the earlier work.

As is shown on Figure 1, in all species over 97\% of total crude protein (CP) was present in the cotyledon fraction and only about $2.5 \%$ in the hull fraction. The distribution of total fat was similar, from 95.5 to $98.1 \%$ was present in the cotyledon fraction, and only from 1.9 to $4.5 \%$ in the hull fraction. In many reports it has been proved that both protein and fat of lupin seeds are well digested by chickens (Alloui et al., 1994), in the small intestine of pigs (Gdala et al., 1994), by pigs and sheep (Tae Hong Kang et al., 1989), and by rats (Zduńczyk et al., 1994). 
TABLE 2

Chemical composition of whole lupin seeds, \% of DM

\begin{tabular}{|c|c|c|c|c|c|c|c|c|c|}
\hline Lupin & $\begin{array}{c}\text { Crude } \\
\text { protein }\end{array}$ & $\begin{array}{c}\text { Crude } \\
\text { fat }\end{array}$ & $\begin{array}{c}\text { Crude } \\
\text { ash }\end{array}$ & NFE & $\begin{array}{l}\text { Crude } \\
\text { fibre }\end{array}$ & NDF & $\mathrm{ADF}$ & ADL & $\begin{array}{c}\operatorname{AME}_{\mathrm{N}}{ }^{*} \\
\mathrm{MJ} / \mathrm{kg}\end{array}$ \\
\hline \multicolumn{10}{|l|}{ L. luteus } \\
\hline Juno & 41.06 & 5.31 & 5.67 & 29.48 & 18.48 & 27.39 & 24.01 & 2.19 & 9.02 \\
\hline Popiel & 40.25 & 5.54 & 6.10 & 30.38 & 17.73 & 27.82 & 23.26 & 2.17 & 8.98 \\
\hline Amulet & 42.75 & 3.70 & 5.35 & 31.34 & 16.86 & 25.58 & 22.20 & 1.97 & 8.80 \\
\hline \multicolumn{10}{|l|}{ L. albus } \\
\hline Wat & 28.81 & 10.37 & 5.10 & 39.66 & 16.06 & 23.90 & 21.44 & 3.37 & 8.82 \\
\hline Bardo & 31.06 & 12.79 & 3.90 & 39.36 & 12.89 & 21.63 & 18.34 & 2.51 & 9.99 \\
\hline Hetman & 34.56 & 11.24 & 4.04 & 38.60 & 11.56 & 19.31 & 16.86 & 1.73 & 10.04 \\
\hline \multicolumn{10}{|c|}{ L. angustifolius } \\
\hline Sur & 28.94 & 6.12 & 4,46 & 43.10 & 17.38 & 27.30 & 22.97 & 2.50 & 7.49 \\
\hline Emir & 32.75 & 6.88 & 4.07 & 42.14 & 14.16 & 23.66 & 19.95 & 1.66 & 8.36 \\
\hline Saturn & 33.31 & 4.70 & 4.46 & 40.15 & 17.38 & 27.30 & 22.97 & 2.50 & 7.70 \\
\hline
\end{tabular}

* calculated according to equations given in European Table of Energy Value for Poultry Feedstuffs (1989)

TABLE 3

Chemical composition of cotyledons, \% of DM

\begin{tabular}{lccccccccc}
\hline Lupin & $\begin{array}{c}\text { Crude } \\
\text { protein }\end{array}$ & $\begin{array}{c}\text { Crude } \\
\text { fat }\end{array}$ & $\begin{array}{c}\text { Crude } \\
\text { ash }\end{array}$ & NFE & $\begin{array}{c}\text { Crude } \\
\text { fibre }\end{array}$ & NDF & ADF & $\begin{array}{r}\text { ADL } \\
\begin{array}{c}\text { AME } \\
\text { MJ/kg }\end{array}\end{array}$ \\
\hline $\begin{array}{l}\text { L. luteus } \\
\quad \text { Juno }\end{array}$ & 54.56 & 7.81 & 2.42 & 31.41 & 3.80 & 19.10 & 6.09 & 2.24 & 12.12 \\
$\quad \begin{array}{l}\text { Popiel } \\
\text { Amulet }\end{array}$ & 53.49 & 8.50 & 6.76 & 27.37 & 3.88 & 14.21 & 6.53 & 1.43 & 12.11 \\
$\quad 56.46$ & 6.08 & 5.99 & 27.81 & 3.66 & 13.15 & 4.67 & 2.11 & 11.81 \\
L. albus & & & & & & & & & \\
$\quad$ Wat & 35.78 & 13.60 & 5.13 & 40.13 & 5.36 & 16.91 & 9.74 & 1.41 & 11.05 \\
$\quad$ Bardo & 37.51 & 15.56 & 4.32 & 37.65 & 4.96 & 11.70 & 6.80 & 1.67 & 11.94 \\
$\quad$ Hetman & 41.59 & 13.82 & 4.78 & 35.68 & 4.13 & 9.14 & 8.13 & 1.20 & 12.02 \\
& & & & & & & & & \\
L. angustifolius & & & & & & & & & \\
$\quad$ Sur & 37.62 & 8.97 & 4.63 & 45.10 & 3.68 & 13.05 & 5.31 & 1.88 & 9.90 \\
$\quad$ Emir & 39.72 & 9.42 & 2.87 & 44.84 & 3.14 & 11.15 & 4.84 & 1.37 & 10.40 \\
$\quad$ Saturn & 44.51 & 7.42 & 4.40 & 40.54 & 3.13 & 9.71 & 5.42 & 2.10 & 10.46 \\
\hline
\end{tabular}

* as in Table 2 
TABLE 4

Chemical composition of hulls, \% of DM

\begin{tabular}{lccccccccc}
\hline Lupin & $\begin{array}{c}\text { Crude } \\
\text { protein }\end{array}$ & $\begin{array}{c}\text { Crude } \\
\text { fat }\end{array}$ & $\begin{array}{c}\text { Crude } \\
\text { ash }\end{array}$ & NFE & $\begin{array}{c}\text { Crude } \\
\text { fibre }\end{array}$ & NDF & ADF & $\begin{array}{c}\text { ADL } \\
\begin{array}{c}\text { AME } \\
\text { MJ } / \mathrm{kg}\end{array}\end{array}$ \\
\hline L. luteus & & & & & & & & & \\
$\quad$ Juno & 5.22 & 0.96 & 6.28 & 24.45 & 63.09 & 85.73 & 76.48 & 2.74 & 1.56 \\
$\quad$ Popiel & 5.18 & 1.06 & 2.66 & 32.23 & 58.87 & 82.52 & 73.15 & 3.75 & 1.71 \\
$\quad$ Amulet & 4.40 & 1.09 & 2.48 & 30.24 & 61.79 & 87.66 & 74.77 & 3.35 & 1.56 \\
L. albus & & & & & & & & & \\
$\quad$ Wat & 3.73 & 0.98 & 2.99 & 29.41 & 62.89 & 85.22 & 76.97 & 4.23 & 1.40 \\
$\quad$ Bardo & 3.56 & 1.07 & 2.66 & 32.31 & 60.40 & 88.04 & 76.76 & 7.45 & 1.45 \\
$\quad$ Hetman & 4.33 & 1.25 & 2.57 & 34.19 & 57.66 & 82.31 & 72.56 & 5.47 & 1.66 \\
$\quad$ L. angustifolius & & & & & & & & & \\
$\quad$ Sur & 4.02 & 1.11 & 3.39 & 32.26 & 59.22 & 81.84 & 70.51 & 3.35 & 1.54 \\
$\quad$ Emir & 2.91 & 0.97 & 4.20 & 33.10 & 58.82 & 83.51 & 71.69 & 3.52 & 1.32 \\
$\quad$ Saturn & 3.58 & 0.89 & 2.82 & 31.35 & 61.36 & 83.59 & 74.93 & 3.80 & 1.38 \\
\hline
\end{tabular}

* as in Table 2

However, the cotyledon fraction also contains about $30 \%$ of cell walls and alpha-galactosides (Brenes et al., 1989, Zduńczyk et al., 1994), which are of low nutritional value for non-ruminants, but rather have no detrimental effect on the digestibility of other components of a diet.

Hulls are composed mainly of dietary fibre; in 9 investigated varieties of lupin hulls contained from 82 to $88 \%$ of the NDF and from 70 to $76 \%$ of the ADF (Table 4). In the hull fraction from 76 to $84 \%$ of total crude fibre (CF), from 70 to $81 \%$ of total ADF and from 63 to $68 \%$ of total NDF of the seed could be found (Figure 1).

As reported by many authors (Brillouet and Riochet, 1983; Dandanell Daveby and Äman, 1993) hulls of lupin are composed mainly of cellulose, galactomannans, pectic acids and arabinogalactans, the proportion of lignin being very low (1.3-2.1\% of DM). According to Brillouet and Riochet (1983) among hull polysaccharides, the following sugars predominate, glucose $(35-56 \%)$, xylose (7.4-18.5\%) and arabinose (3.8-9.7\%). Tae Hong Kang et al. (1989) reported that hulls of white lupin were better digested by sheep than pigs (DE 3278 vs. $2669 \mathrm{kcal} / \mathrm{kg}$ ) and their true metabolizable energy for poultry was very low: hulls 1930, whole seed 2890 and dehulled seed $3550 \mathrm{kcal} / \mathrm{kg}$.

Metabolizable energy $\left(A M E_{N}\right)$ of the whole seeds, calculated according to equations given in the European Tables (1989), ranged from 7.70 to $10.04 \mathrm{MJ} / \mathrm{kg}$ (Table 2), dehulled seeds from 9.90 to 12.12 (Table 3 ), but the hulls only from 1.32 to $1.66 \mathrm{MJ} / \mathrm{kg}$ (Table 4). It seems that the difference in the utilization of lupin hulls between ruminants and poultry is so big that it may justify the cost of dehulling. 
a) Crude protein
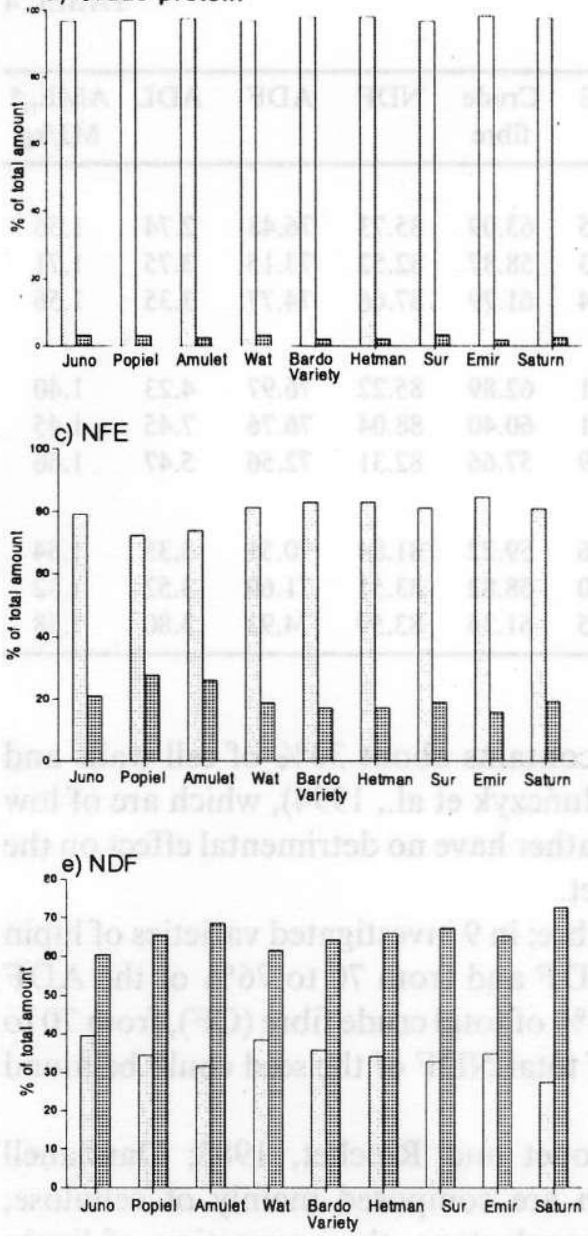

b) Crude fat

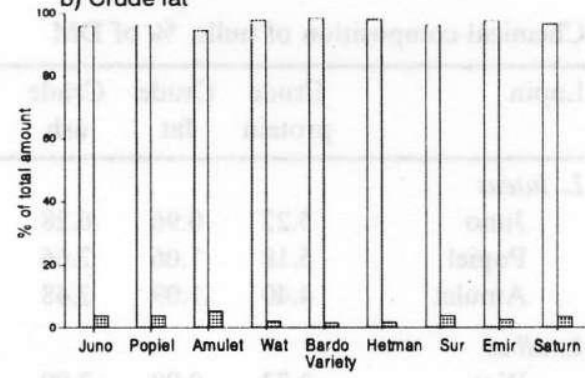

d) Crude fibre
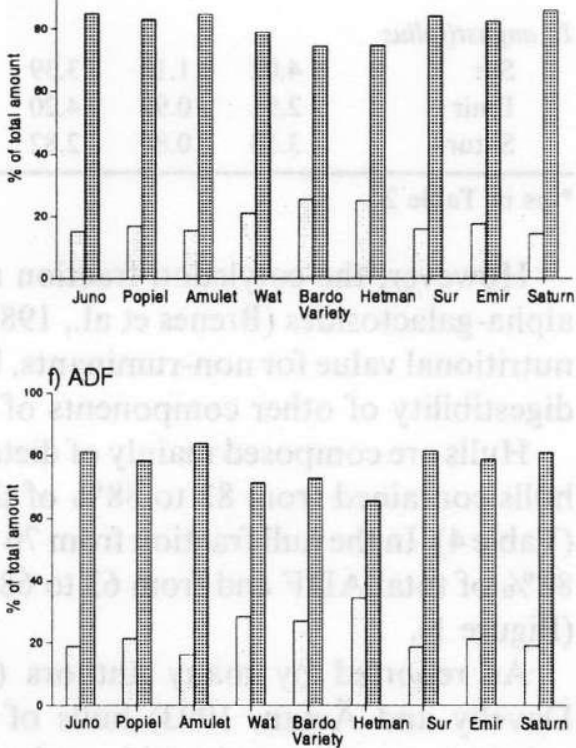

. g) ADL

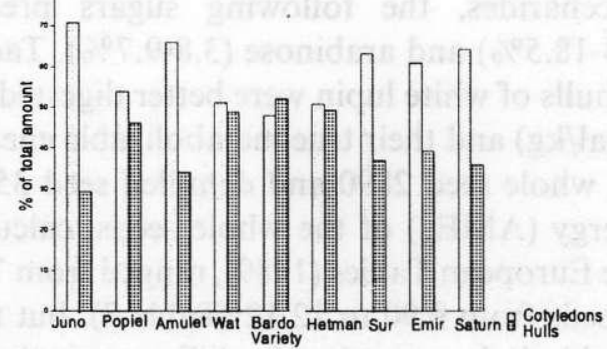

Figure 1. Distribution of components of the whole lupin seeds between cotyledon and hull fractions (total amount in the whole seeds as 100) 


\section{CONCLUSIONS}

The size of the seed (expressed as the weight of 1000 seeds) in L. albus and L. angustifolius is positively correlated with the proportion of cotyledons in it, as well as with the content of main nutrients (protein + fat). Dehulling of lupin seeds may increase their metabolizable energy for poultry by $20-35 \%$. The remaining hull fraction may be utilized as a valuable source of energy for ruminants.

\section{REFERENCES}

Alloui O., Smulikowska S., Chibowska M., Pastuszewska B., 1994. The nutritive value of lupin seeds ( $L$. luteus, $L$. angustifolius and $L$. alhus) for broiler chickens as affected by varicty and enzyme supplementation. J. Anim. Feed Sci. 3, 215-227

AOAC. 1990. Official Methods of Analysis of the Association of Official Analytical Chemists, 5th ed., Chapter 32

Brenes A., Marquardt R. R., Guenter W., Rotter B. A., 1993. Effect of enzyme supplementation on the nutritional value of raw, autoclaved and dehulled lupins (Lupinus albus) in chicken diets. Poultry Sci. 72, 2281-2293

Brillouet J. M., Riochet D., 1983. Cell wall polysaccharides and lignin in cotyledons and hulls of secds from various lupin (Lupinus L.). J. Sci. Food Agric. 34, 861-868

Dandanell Daveby Y. D., Äman P., 1993. Chemical composition of certain dehulled legume seeds and their hulls with special reference to carbohydrates. Swcdish J. Agric. Res. 23, 133-139

European Table of Energy Value for Poultry Fecdstuffs. 1989. Publ. Group No 2, Nutrition, European Federation WPSA. Beekbergen, The Netherlands

Gdala J., Buraczewska L. , Jansman A. M. J., Wasilewko J., van Leeuwen P., 1994. Ileal digestibility of amino acids and carbohydrates in lupins for young pigs. Proccedings VI Symposium on Digestive Physiology in Pigs, Bad Doberan, Vol. I, pp. 93-96

Matyka S., Przcgalińska B., 1986. Fatty acids of fodder lupin seeds (in Polish). Biul. inf. Przem. Pasz. 3. 33-38

Soest Van P. J., Wine R. II., 1967. Use of detergents in the analysis of fibrous feeds. IV. Determination of plant cell-wall constituents. J. Assoc. Ofr. Anal. Chem. 50, 50-55

Tac Hong Kang. Young Ho Cha, Cheol Sung Moon, Chong Nam Ahn, Sang Cheol Lee., 1989. Studies on the chemical composition and digestible nutricnts of $A$ ustralian lupin seed. Res. Rept. RDA (L), 31, 29-35

Zduńczyk Z., Juśkiewicz J., Frejnagel S., Flis M., Godycka I., 1994. Chemical composition of the cotyledons and seed coat and nutritional valuc of wholc and hulled seeds of yellow lupin. J. Anim. Feed Sci. 3, 141-148 


\section{STRESZCZENIE}

Sklad chemiczny bielma i luski trzech gatunków lubinu slodkiego

Dziewięć odmian lubinów słodkich ze zbiorów 1993 roku (żóte: Juno, Popiel i Amulet; białe: Wat, Bardo i Hetman; wąskolistne: Sur, Emir i Saturn) różniących się wielkością nasion obluszczono ręcznie. Oznaczono skład chemiczny całych nasion. luski i nasion obłuskanych.

Stwierdzono, jc wiclkość nasion, mierzona jako ciężar 1000 nasion, jest w łubinach białych i wąskolistnych dodatnio skorelowana $z$ udzialem $w$ nich frakcji bielma oraz z zawartością głównych składników odżywczych (bialka i thuszczu). Niezalcżnic od odmiany około $97 \%$ białka i od 95 do $98 \%$ thuszczu zawartego $w$ nasionach znajdowalo siç we frakcji biclma, natomiast od 74 do $86 \%$ whókna surowego znajdowało się we frakcji luski. Obłuszczenie lubinu może więc zwiększyć jego energie metaboliczną dla drobiu o 20 do $35 \%$. 